INTERNATIONAL CONFERENCE OF ZAKAT 2019 PROCEEDINGS

ISSN: 2655-6251

\title{
The Potential of Application of Technology Based Innovations for Zakat Administration in India
}

\author{
Aishath Muneeza and Shahbaz Nadwi \\ International Center for Education in Islamic Finance (INCEIF) \\ Paper to be presented at International Conference of Zakat 2019 \\ 3-4 October, Universitas Padjadjaran, Bandung, Indonesia
}

\begin{abstract}
India is the home country for many Muslims and effective management of zakah is essential to the country. In this era of technology, it is imperative to fuse technology with zakat to ensure that the classical zakat administration approaches are upgraded to the uruf or customary practices of the society. The objective of this paper is to find out the potential of using technology in upgrading zakat administration in India. This is a qualitative approach where the primary sources such as zakat administration laws in India and secondary sources such as journal articles and published reports on the subject are analysed to derive conclusions. The findings of this paper suggests that the innovations such as rice ATMs, mobile applications, applications made with blockchain technology, artificial intelligence and big data can also play a vital role in the effective management of zakat in India. It is anticipated that the outcome of this research will assist the zakat administrators in India to adopt technology in this regard.
\end{abstract}

Keywords: Artificial intelligence, big Data, fintech, rice ATM, zakat

\section{INTRODUCTION}

In Islam, Zakat is third pillar of the religion Islam. Every Muslim who is capable of paying zakat shall do so without an excuse. In Islam, there are two types of zakat; which is zakat al fitr and zakat al maal. Irrespective of the country in which a person resides and the legal system adopted by the country, every Muslim is obliged to pay Zakat as long as the person fulfils the religious requirements to give it. In simple term, zakat can be defined as alms giving.

Zakat literally means to purify or increase or grow. This literal meaning of zakat indicates that via zakat a person's wealth can be purified and this lead one's wealth to grow and be increased not only physically; but spiritually as paying zakat leads to increase of barakah (blessing) of Allah (SW) in one's wealth. In the Holy book of Muslim, Al Quran, more than 30 different verses Allah (SW) has mentioned zakt. In AL-Quran Zakat has been described as a way in which the redistribution of wealth is practiced in an economy considering the rights of the poor that must be fulfilled by those who are financially capable in the society.

After Indonesia, India is the largest country in terms of Muslim population. It is estimated that there are 17.18 crore Muslims in India accounting for 14.2 per cent of India's population and there is no exact estimate on how much Zakat is collected in India, with estimates fluctuating between Rs 7,500 crore and Rs 40,000 cr annually (Shaikh, 2019). As such, administration of zakat in India is important and there is need to effectively manage zakat. The objective of this paper is to suggest the ways in which technology could enhance the administration 
of zakat in India. This paper is divided into four parts. Followed by this introduction, part two discusses the existing zakat administration practices in Indian while part three explains the technological innovations made in different parts of the world to administer zakat which India could adopt. The final part of the paper deals with conclusion.

\section{LITERATURE REVIEW}

\section{Administration of Zakah in India}

In India, there is no central system for zakat administration as zakat is a personal matter. As such, in different states, there are various private zakat managers like NGOs who deal with zakat or zakat payment and distribution becomes a personal matter handled by the individuals.

In May 2019, it was reported that there was a survey conducted across India by the Association of Muslim Professionals (AMP), who sent questionnaires to 4,589 respondents from across various social strata to understand the current practices of Zakat collection, distribution and its impact on Muslim community (Shaikh, 2019). This survey revealed that 77 per cent of respondents believe that zakat has the potential to transform the Muslim community in India and the main concern they raised was thought zakat money is being given for various purposes, there is no specific focus and the as payers of zakat they have concerns on not knowing the impact created in the sense that they do not know whether the money they give is having any tangible impact on the lives of those who received it (Shaikh, 2017). The findings of this survey also reveal that 36 per cent of the respondents paid less than Rs 10,000 as Zakat. 39 per cent paid Rs 10,000-50,000, five per cent paid Rs 50,000-Rs 1 lakh and 10 per cent over Rs 1 lakh and most donations are given by individuals to their own relatives, with 38 per cent saying they preferred paying charity to their less well-off relatives (Shaikh, 2017). Only 16 per cent of respondents paid money to NGOs or community organisations and funding an individual's education was the most preferred form of paying Zakat (Shaikh, 2017). However, with only 18 per cent paying Zakat for education, the number was relatively less (Shaikh, 2017). Over 50 per cent tended to pay Zakat to the same people and over 55 per cent claimed that the money they gave as charity to someone did not change the life of the family nor were the donors interested in finding out whether the money was being used effectively (Shaikh, 2017). Nearly 47 per cent of the respondents preferred the money being given for the educational empowerment of the community (Shaikh, 2017).

AMP is one of the zakat collectors in the country which has more than 75 chapters across the country which is a registered society under Societies Registration Act 1860, Maharashtra, Mumbai of which the registration number is. 2011 G. B. B. S. D 3001 (AMP, N/A). AMP has their own zakat fund and they publish the performance of their zakat fund in their official website. The official website indicates that AMP zakat fund was created in 2013 to empower lives of their people by promoting education \& self-employment. The information of AMP zakat fund between 2013- 2018 are illustrated in the table 1 . 
Table 1. Performance of AMP Zakat Fund between 2013-2018

\begin{tabular}{|c|c|c|c|c|c|c|}
\hline Figures/Year & $\begin{array}{l}\text { Year } \\
2013\end{array}$ & $\begin{array}{l}\text { Year } \\
2014\end{array}$ & $\begin{array}{l}\text { Year } \\
2015\end{array}$ & $\begin{array}{l}\text { Year } \\
2016\end{array}$ & $\begin{array}{l}\text { Year } \\
2017\end{array}$ & $\begin{array}{l}\text { Year } \\
2018\end{array}$ \\
\hline Total Zakat Fund Collected & $2,06,000$ & $7,99,000$ & $20,65,040$ & $38,79,750$ & $43,25,776$ & $69,62,803$ \\
\hline Total Zakat Fund Distributed & $2,00,000$ & $7,75,773$ & $20,60,000$ & $38,66,000$ & $43,07,150$ & $69,42,300$ \\
\hline Balance & 6,000 & 23,227 & 5,040 & 13,750 & 18,626 & 20503 \\
\hline $\begin{array}{l}\text { Fund Utilized for Higher } \\
\text { Education }\end{array}$ & $1,00,000$ & $4,00,773$ & $10,60,000$ & $10,30,000$ & $15,57,150$ & 2383500 \\
\hline $\begin{array}{l}\text { Fund Utilized for Self } \\
\text { Employment }\end{array}$ & $1,00,000$ & $3,75,000$ & $10,00,000$ & $12,65,000$ & $14,25,000$ & 2500000 \\
\hline $\begin{array}{l}\text { Fund Utilized for Orphans } \\
\text { Scholarship }\end{array}$ & - & - & - & $5,73,000$ & $10,25,000$ & 2018800 \\
\hline Fund Utilized for IIT Scholarship & - & - & - & $8,50,000$ & - & - \\
\hline $\begin{array}{l}\text { Fund Utilized for Specific } \\
\text { Donations }\end{array}$ & - & - & - & $1,48,000$ & $3,00,000$ & 40000 \\
\hline $\begin{array}{l}\text { Beneficiaries for Higher } \\
\text { Education }\end{array}$ & 10 & 41 & 106 & 103 & 112 & 167 \\
\hline $\begin{array}{l}\text { Beneficiaries for Self } \\
\text { Employment }\end{array}$ & 5 & 18 & 42 & 50 & 71 & 89 \\
\hline $\begin{array}{l}\text { Beneficiaries for Orphans } \\
\text { Scholarship }\end{array}$ & - & - & - & 120 & 174 & 324 \\
\hline Beneficiaries for IIT Scholarship & - & - & - & 5 & - & - \\
\hline $\begin{array}{l}\text { Beneficiaries for Specific } \\
\text { Donations }\end{array}$ & - & - & - & 6 & 1 & 1 \\
\hline Total Beneficiaries & 15 & 59 & 152 & 284 & 358 & 581 \\
\hline
\end{tabular}

Source: Official Website of AMP

Table 1 indicates that year by year, the zakat collection of AMP has been growing and every year AMP ensures that the zakat collected money is disbursed. This proves that AMP has been conducting initiatives to make public aware about the existence of their zakat fund and the transparent disclosure made by them may have increased the confidence of public in entrusting zakat money to them. AMP has also disclosed their zakat plan for 2019 in their official website where they have stated that the zakat fund collected in 2019 will be utilised for the purposed illustrated in Table 2 (below).

Table 2. AMP Zakat Disbursement Plan 2019

\begin{tabular}{|l|l|}
\hline $\begin{array}{l}\text { Support A Higher } \\
\text { Education }\end{array}$ & $\begin{array}{l}\text { Wherein a yearly support of } \\
\text { Rs.10,000/- (Rupees Ten } \\
\text { Thousand) is given to students } \\
\text { pursuing Higher Education in } \\
\text { the fields of Engineering, } \\
\text { Medicine, Architecture, etc. By } \\
\text { this endeavor AMP hopes that } \\
\text { the worries of the student } \\
\text { getting assistance would be } \\
\text { reduced to some extent and they } \\
\text { can focus better on their }\end{array}$ \\
\hline
\end{tabular}




\begin{tabular}{|l|l|}
\hline & $\begin{array}{l}\text { education and try to build a } \\
\text { good base for themselves. }\end{array}$ \\
\hline $\begin{array}{l}\text { Support A Small } \\
\text { Business - Make A }\end{array}$ & $\begin{array}{l}\text { Wherein a support of } \\
\text { Rs.25000/- (Rupees Twent Five } \\
\text { Thousand) is given to any needy } \\
\text { Muslim person/ family to start a } \\
\text { source of income. Through this } \\
\text { endeavor AMP firmly hopes } \\
\text { that the Zakat Taker of today } \\
\text { becomes the Zakat Giver of } \\
\text { tomorrow. }\end{array}$ \\
\hline Support an Orphan & $\begin{array}{l}\text { AMP has decided to support the } \\
\text { educational expenses of a needy } \\
\text { orphan child so that the child is } \\
\text { not deprived of even the basic } \\
\text { education for want of a } \\
\text { guardian. Through this endeavor } \\
\text { AMP intends that the orphans in } \\
\text { the community should not feel } \\
\text { left behind or isolated and the } \\
\text { community is right behind them } \\
\text { to support them. }\end{array}$ \\
\hline
\end{tabular}

Source: Official Website of AMP

AMP also disclosed in their official website the bank account to which the zakat money could be deposited and they have disclosed that no administration fee or a cost will be charged for this. Using this information about AMP zakat fund, it is understood that in India there is a decentralization zakat administration model where private parties who wish to do so have the autonomy to deal with it. Other than AMP, there are many other organizations that do zakat administration in similar manner which are located in different parts of the India such as Zakat Foundation of India which was established in 1997 which is a Non-Governmental/NonProfit Organization which collects and utilizes 'zakat' or charity for socially beneficial projects in a transparent and organized manner (Zakat Foundation of India, N/A). Since there are various organizations managing zakat in India, for the purpose of this paper, AMP will be used for a case study.

\section{RESULTS \& DISCUSSION}

\section{Use of Technology in Zakat in India}

In the case of AMP Zakat fund, it is found that there is no use of technology at all in collection or disbursement of zakat fund. The procedure used is purely based on a bank transfer made to the account or via a cheque sent to the address provided in the website. This proves that there is scope for application of technology by organizations like AMP in India who deals with Zakat. This part of the paper will provide the type of technology that has been adopted in different parts of the world which India could adopt in this regard.

\section{Rice ATMs}

Rice Automated Teller Machines (ATMs) provide rice for needy without the involvement of a human similar to how cash is dispensed via Bank ATMs. A portion of Zakat money need to be allocated for the poor and there is need to ensure that a proper mechanism in a less costly manner could be made make this possible. In Malaysia, these Rice ATMs have been installed in mosques (Nordin, 2019) and this is indeed something which India shall consider as well.

In February 2019, it was announced that The Federal Territories Islamic Religious Department (Jawi) hopes to install 'rice ATM machines' at 85 mosques in the Federal Territory to facilitate its 23,000 asnaf or tithe recipients (Bernama, 2019). It is reported by Bernama (2019) that the cost of this machine isRM19,000 and is the first in the country and it has two functions, namely to give out rice supply in desired quantity and has a donation box to receive funds from the public. On February 15th, first rice ATM machine 
was installed at Al-Akram Mosque in Kampung Datuk Keramat.

The main purpose of the Rice ATMs is to provide assistance to recipients (asnaf/beneficiaries of zakat) who are registered as poor for zakat purpose to collect rice using a special card provided to them for this purpose. The modus operandi of these rice ATM's is that the user of the ATM machine must tap the special card they have for the purpose on the sensor of the machine and then the machine will dispense $2 \mathrm{kgs}$ of through the designated collection point in the machine which is located in the base of the machine. In this special rice ATM machine, those who wish to donate money for the purpose can also do so by depositing cash through a slot in the machine.

Though this is the first time Rice ATMs are used in Malaysia, rice ATMs were innovated for zakat purpose by National Board of Zakat, Badan Amil Zakat Nasional (BAZNAS), Indonesia and the machine was created by one of alumni of Bandung Technology Institute (Institut Teknologi Bandung or ITB). It was reported in the official website of BAZNAS on 17th January 2017 that the machine in Arthaloka building is a prototype of ATM machines which soon to be assembled in ten several location points in Jabodetabek, such as BAZNAS Office (Kebon Sirih Street No. 57 Jakarta) and nine mosques which are cooperated with BAZNAS. Each unit of ATM can store up to 230 litres rice capacity, which can fulfill the needs of 120 households. Then, each unit can be refilled eight times per month. It was also stated that the Rice ATM program is also in line with the BAZNAS support to continuing SDGs in order to eliminate the food shortages for poor people.
It is essential to understand the way how the Rice ATMs work. In Sindonews, it was stated that the BAZNAS rice, measuring $60 \mathrm{~cm} \mathrm{x} 60 \mathrm{~cm}$ $\mathrm{x} 160 \mathrm{~cm}$, shaped like a closet box and is very similar to a regular ATM machine and the rice ATM is equipped with electronic devices that hybrid network modem GSM/satellite as well as control and monitoring system based machine to machine (M2M) or Internet of Things (IOT). The machine can remove the rice in a certain amount automatically and the way it works is that the rice out by attaching the card Radio Frequency Identification (RFID) at the sensor card reader on the device. It was reported that each rice ATM unit has a storage capacity of $1,000 \mathrm{~kg}$ of rice to meet the needs for 1,000 recipients and each unit will be recharged as many as eight times in one month. The cost of manufacture and maintenance in a year to Rp30 million per unit and one-time transaction can draw rice from $1 \mathrm{~kg}$ and $2 \mathrm{kgs}$. Rice ATM cards are issued by the mosques.

The questions that might be asked are: why a rice ATM and why not just money? Or why is it placed in a mosque; rather than a shop or a bank or elsewhere? On 28th February 2019, it was reported that a mosque in North Jakarta provides rice machine for the poor and this program to provide rice ATMs began on 13th January 2019 where at least 33 urban poor had received four free liters of rice twice a week from the machine (The Jakarta Post, 2019). It was reported that Barnas Sumantri, the head of the Jami Raudlatul Jannah Mosque's Welfare Council, said the rice ATM, which provides charity to the less fortunate living around the mosque, operates every Wednesday and Sunday. Barnas has explained the reason behind giving rice and the benefit of it as 
follows: "by giving rice [as charity], we can feed a whole family. If we give money, Rp 100,000 [US\$7] for example, it might only be enough for one or two persons". It was also reported that the reason why Wednesday and Sunday is chosen is because these are the days the mosque conducts religious studies. As such, there is multiple benefits of choosing these days and Barnas has described these benefits as: "they can get multiple benefit. The pahala [reward], the knowledge and the rice. The mosque had given special ATM cards to each of the beneficiaries and in order to get the rice, the cardholders only have to tap their cards on the machine and the rice flows into a container.

\section{Mobile Apps}

Today the use of smart mobile phones are widespread. Therefore, the use of mobile app for convenience has become a life style. In some countries such as Malaysia mobile apps have been introduced for ease zakat administration. In June 2018, it was reported in the official website of Lembaga Zakat Selangor (LZS) that they have introduced mobile apps to Penolong Amil Fitrah (PAF) to make fitrah zakat collection in Selangor (Lembaga Zakat Selangor, 2018). It was stated that this project involved 200 selected PAF in Selangor and through these mobile apps, PAF no longer uses a coupon of nature as evidence of zakat payments, instead using mobile apps to issue zakat payments in the field. To make this possible, each involved PAF is given a RM50 smart card, printer and internet access facility. Zakat producers only need to provide identification cards for information scans for storage purposes at LZS and the PAF will print the receipt once payment of zakat fitrah is made. This application is supported by a link to the LZS system and it has number of security features embedded. Every personal information of the zakat payers is recorded more efficiently and easily into the LZS system and also the payment bills via immediate withdrawal receipts also increase the trust level of zakat producers with LZS. The advantage of using such an app include reducing the risk of losing the physical coupons as physical coupons that need to be taken anywhere.

3. Zakat Payment via Payment Gateway from Website

Time is money and a convenient mechanism is required to pay zakat money. Having a website to provide only information is not enough today and it is imperative to have features like making payments via website. It is suggested that India could adopt this convenient way of payment of zakat. A perfect example of this could be the case of Malaysia where Lembaga Zakat Selangor has introduced e-zakat pay which is an online zakat payment method at www.zakatselangor.com.my (Lembaga Zakat Selangor, N/A). It is stated that ezakat pay is an online financial transaction platform that links between banks to make zakat payment to the Lembaga Zakat Selangor. There are number of banks which are associated with Lembaga Zakat Selangor to carry out this financial transaction. It is stated that for zakat payment, the payer only need to visit the e-zakat portal at www.zakatselangor.com.my and click on the E-Zakat Pay payment to pay zakat. However, it is a condition precedent for the payer to have an account at the participating bank before proceeding with the payment. Subsequently, the payer shall follow the steps given, and payment of zakat will be completed online. There is no registration and payment needed for 
using e-Zakat Pay and no additional charges are taken for this service. It is imperative that in e-Zakat Pay, there is no need for the payer to download any application. Everything is taken place from the designated website and the entire transaction is secure as it is encrypted with 128 Bit SSL. Also. In eZakat Pay, all payments will be made in real-time online which is the process of debiting from the payer's bank to the payer's account is being carried out at that time and the process of issuing a zakat payment receipt will be done within 14 working days.

\section{Zakat Via Telecommunication Service} Provider

Today, it is an essential to own a mobile phone and as such, everyone owns a mobile sim. An arrangement could be made with the telecommunication provider by the zakat administration organization in India to ensure that there is a convenient mechanism to pay zakat. A good example to illustrate how this work could be taken from Malaysia, where in 2014, it was reported that Celcom Axiata Berhad, the first and foremost mobile telecommunications provider in the country, facilitated the Muslim customers to pay for their zakat fitrah, anytime and anywhere through the telco's M-Fitrah service (CELCOM, 2014). It was stated that the M-Fitrah service was available in three (3) payment options; SMS, USSD, WEB and WAP. In this case, the telecommunication company was an unauthorized collection agent for zakat fitrah, offering the M-Fitrah service to its Muslim customers in Selangor, Melaka, Kedah, Perlis, Terengganu, Pahang, Sabah and Kelantan. In M-Fitrah service, customers are required to enter "FITRAH $<$ space $><$ STATE $>$ " and send it to 21999 or dial $* 888 * 33 \#$ for the payment of zakat fitrah via SMS. Next, they will receive a reply from 21999 and are required to send their " $<\mathrm{NAME}>,<\mathrm{IC}$ Number $>$, <number of dependents $>$ " to the same number. Then a verification message will ensue and if the reply is YES, a thank you message and receipt number for each payment made to self and dependents will be sent back to the customers. For zakat fitrah payment via WEB Page, customers can visit www.thecube.my/mfitrah. Customers will be requested to fill in their details and upon completing the online form, they will receive an SMS from 21999 with a pin code; which has to be keyed in to the page in order to complete the submission. For zakat fitrah payment via WAP Page, customers may visit m.thecube.my/mfitrah and enter their mobile number before clicking the submit button. An SMS will be sent from 12028 providing them with an URL link. Upon selecting the link they will be automatically redirected to the M-Fitrah page or they may select M-Fitrah link from the display page. Customers are required to insert their information and will be redirected to the Lifecube page. Through either one of the Web Page or Wap Page, customers will then receive an SMS to confirm their submitted information and will be required to respond via SMS accordingly. For those who need to modify their details, they will be required to respond SALAH and resubmit their application. Upon confirmation of details, another SMS will be delivered to the customer to confirm on the payment and a receipt of payment will be sent via SMS.

The organizations dealing with zakat in India could easily form a partnership with a telecommunication 
provider and could offer same services to the zakat payers.

\section{Blockchain Applications}

Research is ongoing to integrate blockchain technology to zakat. It is reported that Dr Ziyaad Mahomed, Associate Dean of executive education and e-learning at the International Centre for Education in Islamic Finance (INCEIF), and his team have come up with an Islamic social financing app that leverages blockchain technology. The modus operandi of this app has been summarized by Dr Ziyaad as follows according to the edge markets (2018): "How the app works is very simple. When users turn it on, they are presented with two options: sadaqat (charity) or zakat. If they choose zakat, the app prompts them to select the school of thought they follow — Shafie, Maliki, Hambali or Hanafi — as there are differences of opinion. Then, the app asks a few questions such as where they would like to see their money go. We provide them with a choice of projects such as water irrigation, sanitation, poverty eradication and education. After choosing the project, they complete their payment using a secure gateway. Specific projects are listed. And once the zakat payment has been made, it is registered on a node in the blockchain. Payers will receive confirmation of acceptance. Now, the project has their money. When the money has been fully utilised, the payers will be notified via the app. Thanks to the transparency provided by the blockchain, there is more confidence among payers that their zakat has reached the intended recipients" (Noordin, 2018). This app was developed in partnership with Dublin-based financial technology (fintech) company AidTech and the International Federation of Red Cross and Red Crescent Societies. It was supposed to be launched in the end of last year, but it is not launched yet. This technology based innovation promoted transparency in zakat and sadaqat boosting the confidence of contributors.

In May 2018, it was reported that by Indonesian based Blossom Finance that in Ramadan, Blossom Finance is offering a free service allowing Muslims to pay zakat owed against cryptocurrency holdings directly using the blockchain and these payments collected by Blossom will go towards orphans and widows in Sumatra and Central Java, Indonesia via Blossom's network of cooperatives and nonprofits (Blossom, 2018). It was stated that this service by Blossom is offered free of charge and no payment is charged for using the service. It is stated in the official website of Blossom that how this service works is Blossom will accept payments in cryptocurrency directly via the Blockchain to a Blossom controlled wallet held at a cryptocurrency exchange in Indonesia. Blossom then converts the cryptocurrency to Indonesian Rupiah, and deposits the amount into the bank accounts of their cooperative and nonprofit partners located in rural areas in Indonesia. How this works is summarized in the Figure 1 below: 
Figure 1. Blossom's Procedure to Pay Zakat via Crypto Currency
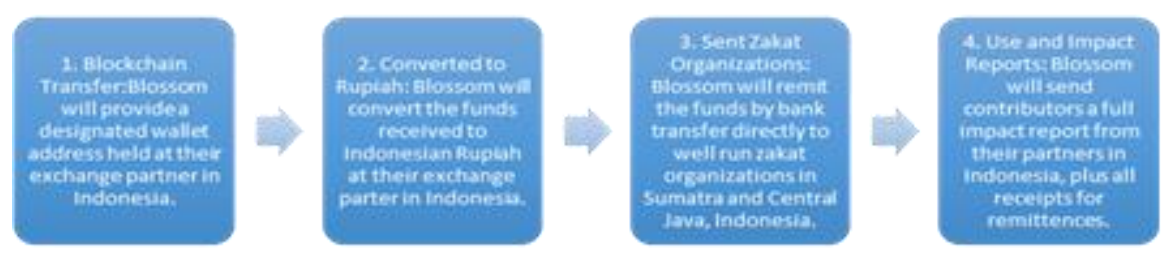

Source: Information extracted from the official website of Blossom

With regards to the issue of exchange fees it was stated that Blossom has consulted with their internal shariah advisory and they have been advised that exchange fees incurred when converting from cryptocurrency to local currency qualify as part of the total zakat payment. Bearing this in mind, it is stated that Blossom will try their best to trade the crypto in a way that incurs minimal or no fees. It is essential to note that Blossom Finance has published a working paper on the permissibility of Bitcoin and cryptocurrency and has concluded that bitcoin qualifies as Islamic money, except where banned by local government, but cautions investors against speculation, initial coin offerings (ICOs) and investment schemes. Blossom Finance helps institutions to raise costeffective, Shariah-compliant financing from global investors using blockchain technology on its Smart Sukuk platform. Blossom was founded in 2014 to increase the availability of halal financial products using technology. Since 2015, Blossom has been helping microfinance institutions in Indonesia raise funds from international investors to fund microbusinesses aimed at reducing regional poverty.
To make zakat administration more efficient and transparent the use of blockchain technology with smart contracts could be used in India as well.

\section{Artificial Intelligence}

The functions performed by humans are being replaced by machines and artificial intelligence is being utilized in the financial industry now. Another innovation we see is zakat chatbots powered with artificial intelligence technology replacing the officers who provide information about zakat and on the calculation of it. This could be described as an improvised version of the simple zakat calculators we use now. In this regard, Al-Riyami, et. Al. (2014) from Sultan Qaboos University of Oman have presented in 15th European Conference on Knowledge Management, ECKM 2014 a research on zakat expert system (ES). They state that ES are a part of applied artificial intelligence and the idea of an ES is to convert knowledge from human expertise to a computerized system. The objective of their study is to apply expert system technology in the field of Zakat to assist Muslims in the decision making of identifying the rules 
of making Zakat and to assist in complex calculations. They state that the objective of the Zakat ES is to specifically help people calculate the amount of each type of Zakat they have to pay every year, the system helps users to: (1) determine if they are required to give Zakat, (2) determine the unique conditions, and the amount of each type of Zakat they have to pay every year. The system was developed based on a rules-based expert system shell. To develop such a system, information that is attained from a human expert is represented in the form of rules, such as IF-THEN. Then the rules are used to perform operations that lead into achieving certain goals. It is stated that after reviewing the Zakat expert system, the majority of the 20 potential users also indicated that the system saves time and effort in searching for information related to Zakat's rules. Users also indicated that it is very useful for calculating Zakat quickly and accurately, and is very beneficial, convenient, and easy to use for people who have no knowledge about Zakat. Other strengths of the system are that it is more convenient than going to human experts and provides a variety of Zakat types.

In 2017, Pahang Zakat Collection Center (PKZ) has also introduced a chatbot called ZakatChat (APPAGG, N/A). ZakatChat is an artificial intelligence-based application provided by PKZ to smartphone users and visitors to PKZ's official website to interact and help answer questions about zakat property. It is stated in their official website that ZakatChat uses a specially programmed search engine technology to match questions asked with available databases. In addition, ZakatChat also guides users to obtain additional information from other mediums if the information is not available in the ZakatChat database.

In 2018, in collaboration with PT Artina Digitama Indonusa (Artdigi), the Baznas of Indonesia launched a Zakat Virtual Assistant Chatbot named "Zaki" for the first time in Indonesia (The Jakarta Post, 2018). It was reported that Zaki can be accessed on the LINE messenger application under the name @ zakibaznas and in the near future it will be available on the Facebook Messenger chat application and the community can calculate the amount of zakat accurately, literacy, and zakat education as well as information on Baznas social and humanitarian programs. Zaki's features that will be coming soon include maps of the nearest mosque location, prayer schedule reminders to da'wah material. With chatbot technology that is equipped with Natural Language Process, it allows this feature to be able to chat with users to analyze the wishes of the users. Apart from the chatbot, BAZNAS has developed an internal platform, for donation services through the BAZNAS website (baznas.go.id/zakatsekarang) and through the Muzaki Corner application service. An external platform, where the platform comes from BAZNAS partners who provide special space and options for the community to zakat through BAZNAS. Some of the examples for this are the option of zakat and charity through kitabisa.com, gojek, bukalapak, tokopedia, and others. Apart from this social media platform to facilitate direct donations through social media is made. National Zakat Index (IZN) is also introduced to measure zakat. BAZNAS has also a plan to introduce an electronic commerce platform to increase market access for mustahik products benefiting the productive zakat program. 
India also can consider using artificial intelligence to improvise zakat administration.

\section{Big Data}

Zakat information or data management also face challenges as information on zakat including the payers, distributors, receivers and other stakeholders need to be maintained and the volume of these data are growing day by day. Big data can resolve this. Big data can be described as a technology that enable to analyze, systematically extract information from, or otherwise deal with data sets that are too large or complex to be dealt with by traditional dataprocessing application software. Sulaiman, et.al. (2015) has stated that the main difficulty in handling large amount of data is due to the five big data concepts involving volume, velocity, variety, veracity and value which increases rapidly in comparison to the computing resources and zakat administrators are currently facing issues with the growing amount of data on zakat payers, zakat distribution and various zakat recipients. They state that overwhelming amount of data must be carefully managed by the zakat institutions and the appointed zakat fund trustees as zakat data resides in massive, unstructured information, largely in various forms of numeric, text and imagery, there is a need for zakat institutions to switch to better data management mechanism. Their study proposes a big data maturity model to gauge the readiness of zakat institutions to embark into the big data evolution and the proposed model also provide the zakat institution with more structured processes of managing the high volume of data in order to provide better reporting transparency, making well- informed decisions and instill confidence and trust from the community on better zakat management and distribution.

Indeed big data could be helpful for zakat administration in India too.

\section{CONCLUSION}

It is evident from this paper that currently the use of technology in zakat in administration in India needs to be improved. This paper has suggested some of the technological innovations that could be adopted in this regard. Since this is the era of technology, there is need to adopt technology as the "uruf or customary practices of this generation of humans. As illustrated in this paper, each and every technological innovation has its own unique advantages which will definitely assist in resolving some of the existing issues. There is no lack of Information technology experts in the country and it is hoped that the findings of this paper will assist organizations like AMP to consider using technological innovations to manage zakat.

\section{REFERENCES}

Al-Riyami, A., Al-Harthy, A., Al-Amri, K., \& Al-Busaidi, K. A. (2014). Zakat expert system. In Proceedings of the 15th European Conference on Knowledge Management, ECKM 2014 (Vol. 1, pp. 31-38). Academic Conferences Limited.

Association of Muslim Professionals (AMP), (N/A), What is AMP, retrieved on 1st June 2019 from http://ampindia.org/What_is_AMP

APPAGG, (N/A), Description ZakatChat, retrieved on 1st June 2019 from https://appagg.com/android/booksreference/zakatchat28877078.html?hl=en 
Bernama (2019), 85 mosques in Kuala Lumpur to have rice ATM machines, retrieved on 1st June 2019 from http://www.bernama.com/en/news.php ?id=1697796

Blossom, (2018), Muslims Can Now Pay Zakat in Cryptocurrency, retrieved on 1st June 2019 from https://blossomfinance.com/press/musl ims-can-now-pay-zakat-incryptocurrency

CELCOM, (2014), Press Release: The Easiest Way to Pay Zakat with Celcom M-Fitrah Service, retrieved on 1st June 2019 from https://ocs.celcom.com.my/Web_Cent er_Sites/PBO/Files_Corporate/Media_ Release/2014/2014-July-17.pdf

Lembaga Zakat Selangor, (2018), LZS Introduced Mobile Apps to Ease Penolong Amil Fitrah, retrieved on 1st June 2019 from https://www.zakatselangor.com.my/lat est-news/lzs-introduced-mobile-appsto-ease-penolong-amil-fitrah/?lang=en

Lembaga Zakat Selangor, (N/A), Pay Online, retrieved on 1st June 2019 from

https://www.zakatselangor.com.my/pa $\mathrm{y}$-online/?lang=en

Noordin, K.A. (2018), Islamic Finance: Using blockchain to improve transparency of zakat process, retrieved on 1st June 2019 from https://www.theedgemarkets.com/artic le/islamic-finance-using-blockchainimprove-transparency-zakat-process

Nordin, R. (2019), Rice for the needy via automated teller machine, retrieved on 1st June 2019 from https://www.thestar.com.my/metro/me tro-news/2019/05/30/rice-for-theneedy-via-automated-tellermachine\#V31R15q1rFmtUGgz.99
Shaikh, Z. (2019), Zakat can transform Muslim community: Survey, retrieved on 1st June 2019 from https://indianexpress.com/article/cities /mumbai/zakat-can-transform-muslimcommunity-survey-5707834/

Sulaiman, H. Cob, Z.C. Ali, N, Big data maturity model for Malaysian zakat institutions to embark on big data initiatives, retrieved on 1st June 2019 from

https://ieeexplore.ieee.org/document/7 333084/authors\#authors

The Jakarta Post, (2019), Mosque in North Jakarta provides rice machine for the poor, retrieved on 1st June 2019 from https://www.thejakartapost.com/news/ 2019/02/28/mosque-in-north-jakartaprovides-rice-machine-for-thepoor.html

The Jakarta Post, (2018), BAZNAS launches zakat virtual payment assistant for alms donors, retrieved on 1st June 2019 from https://www.thejakartapost.com/adv/2 018/05/28/baznas-launches-zakatvirtual-payment-assistant-for-almsdonors.html

Zakat Foundation of India, (N/A), About Us, retrieved on 1st June 2019 from http://www.zakatindia.org/AboutUs.ht mlAl-

Aishath Muneeza
INCEIF
Malaysia
muneeza@inceif.org/muneeza@gmail.com

Shahbaz Nadwi

INCEIF

Malaysia 